and Informatization named after Heroes Krut, National University of Defense of Ukraine named after Ivan Chernyakhovsky, Kyiv Institute of the National Guard of Ukraine) are presented.

The leading trends in the development of military education in Ukraine at the beginning of the XXI century are investigated: improvement of the current legislative framework aimed at integrating world standards and building its own military capabilities; transition to a promising system of military education, which involves the termination of correspondence training for state budget funds and the introduction of a system of leadership L-courses to replace existing ones; creation of appropriate conditions for mutual recognition and enrollment of certificates that were obtained in higher military institutions of NATO member states; introduction of advanced methods, means of training, technologies that will contribute to the formation of key competencies of modern military education in the context of world requirements.

Key words: military education, trends, a promising system of military education, leadership courses, the beginning of the 21st century.

Дата надходження статті: 03.11.2021 p.

Рецензент: доктор педагогічних наук, доцент Султанова Н.В.

УДК $378.134(78)$

DOI https://doi.org/10.37915/pa.vi50.325

Савчук Б. П.,

orcid.org/0000-0003-2256-0845

Слюсаренко Н. В.", orcid.org/0000-0002-9215-5936

Білавич Г. В.*,

orcid.org/0000-0002-1555-0932

\title{
КОУЧИНГ: ІДЕЙНІ ВИТОКИ В ПРОЕКЦІЇ ФОРМУВАННЯ ОСОБИСТОСТІ
}

Статтю присвячено проблемі коучингу, який на початку XXI cm. отрихав широке визнання в Украйні, зокрема у галузі освіти. Мета статті - з'ясувати ідейні витоки коучингу задля глибшого розуміння його філософії та використання як ефективної технологї формування особистості. Зазначено, що в украйнському науковому та суспільному дискурсі ияя проблема представлена доволі фрагментарно. У зарубіжній науці їй присвячено чимало спецііальних студій, щзо мають міждисцииплінарний (стосуються галузей спорту, бізнесу, менеджменту, освіти та ін.) та переважно науково-популярний характер. Автори наголошують, щзо в науц̧і досі немае ьрунтовного комплексного дослідження проблеми походження та історії становлення $і$ розвитку коучингу, оскільки цุю проблему переважно висвітлюють фахівиі різних галузей знань зі свойх вузькопрофільних позицій. В украйнському науково-педагогічному дискурсі коучингу утвердилася доволі спрощена модель $i$ «звужена» схема осмислення проблеми виникнення і становлення коучингу. Дослідники акцентують на постаті «основоположника», «фундатора» сучасного коучингу - каліфорнійського тренера з тенісу, викладача Гарвардського університету В. Тімоті Голві (Голиувей - W. Timothy Gallwey), який у книзі «Внутрішня гра в теніс» («The Inner Game of Tennis», 1974) і ще в кількох бестселерах виклав наріжні його ідеі. За результатали аналізу актуалізованих джерел із иіеї проблеми зроблено висновок про те, щзо найбільш виразний, фундаментальний

*(C) Савчук Б. П.

*(C) Слюсаренко Н. В.

*(C) Білавич Г. В.

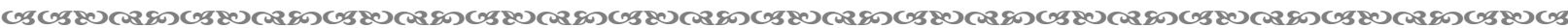
210 
впхив на розвиток філософії коучингу справили чотири ідейних учення та системні практики минулого й сучасного. Це: Сократівські методи діалогу; гуманістичний напрям психотерапії; працзі Д. Гоулмена у сфері емоциійного інтелекту; методики знаних спортивних тренерів. Проаналізовані теорії відомих зарубіжних учених у широкій історичній ретроспективі показують, як спортивне тренерство, акумулювавщи тисячорічний досвід східної $і$ західної культур із фізичного і духовного вдосконалення людини, трансформувалосл в сучасний феномен коучингу.

Ключові слова: коучинг, розвиток особистості, теорії походження, коучингу, Сократівські методи діалогу, тренер.

Постановка проблеми. Щоб усебічно вивчити й ефективно використовувати будь-який освітньо-педагогічний феномен у формуванні особистості, потрібно розуміти його генезу, ідейні витоки, особливості становлення. Це повною мірою стосується коучингу, який на початку XXI ст. отримав широке визнання в Україні й дедалі активніше торує шлях у системі національної освіти. Між тим, в українському науковому та суспільному дискурсі ця проблема представлена доволі фрагментарно, контекстно. У зарубіжжі їй присвячено чимало спеціальних студій, що мають міждисциплінарний (стосуються галузей спорту, бізнесу, менеджменту, освіти та ін.) та переважно науково-попуяярний характер. Це значною мірою пояснює відсутність грунтовного комплексного дослідження проблеми походження та історії становлення і розвитку коучингу, адже їі переважно висвітлюють фахівці різних галузей знань зі своїх вузькопрофільних позицій. Діквідація цієї прогалини потребує проведення грунтовного комплексного міждисциплінарного дослідження, тож пропонована стаття актуалізуе це завдання і розставдяє важдиві акценти в його реалізаціі.

Аналіз досліджень. Західні теоретики й адепти коучингу (М. Аткінсон, Т. Голві, М. Дауні, М. Доуні, К. Дуглас, С. Кові, Д. Уітворт, Дж. Уїтор та ін.) розробиди його наріжні науково-теоретичні засади й технології в проєкції використання в спорті, бізнесі, менеджменті, освіті, психології, інших суспільних сферах. Спираючись на їхній доробок, українські науковці (І. Голіяд, Н. Горук, О. Нежинська, С. Романова, О. Соколова, В. Тименко, Т. Чернова, О. Шевчук та ін.) спричинилися до розробки підходів і засобів використання коучингу в різних ланках системи освіти, передусім у вищій школі. При цьому вітчизняні вчені-педагоги лише фрагментарно, подекуди навіть плутано висвітдюють ідейні витоки коучингу, актуалізують потребу предметного і більш цілісного з'ясування цієї проблеми.

Мета статті - з'ясувати духовні витоки й ідейне коріння коучингу задля гдибшого розуміння його філософії та використання як ефективної технології формування особистості.

Виклад основного матеріалу. В українському, як і в усьому пострадянському науково-педагогічному дискурсі коучингу, утвердилася доволі спрощена модель $\mathrm{i}$ «звужена» схема осмислення проблеми виникнення і становлення коучингу. Головна увага дослідників сфокусована на постаті каліфорнійського тренера 3 тенісу, викдадача Гарвардського університету В. Тімоті Голві (Голлувей - W. Timothy Gallwey), який у книзі «Внутрішня гра в теніс» («The Inner Game of Tennis», 1974) [2] і ще в кількох бестселерах виклав наріжні його ідеї. Він трактується як «основоположник», «фундатор» сучасного коучингу, так що не лише історія, а і його ідейні витоки та інші аспекти розвитку розглядаються крізь призму творчості цієї персоналії.

На відміну від цієї рецепції, у західному міждисциплінарному дискурсі визнається вагома роль Т. Голві в появі та формуванні коучингу, але він цілком справедливо 
розглядається як один із представників плеяди не менш значущих творців і адептів цього феномена, що зробили його надбанням дюдства.

Вивчення здобутків західних авторів спонукає підходити до з'ясування ідейних витоків коучингу в широкому контексті, розглядаючи його як продукт творчої акумуляції різних історіософських, психологічних учень та гуманістичних ідей минулого. Дослідники пропонують різні підходи до цієї проблеми. Зокрема, В. Броску своїх дослідженнях визначила «дев'ять базових коренів (чинників. - Авт.) коучингу»: освіта; психотерапія; комунікація; рух самодопомоги; теорія соціальних систем; спортивна мотивація; теорії розвитку; цілісний рух; управління і лідерство [9; 10].

Дослідник М. Рейс (2014) у статті під назвою «Umahistóriadocoaching» виокремив два головні складники появи коучингу. Перший - філософський, у якому тренер знаходить основні припущення і переконання, що підтримують коучинг. Другий соціальні науки, у яких існують моделі й методи, що становлять основу для практики коучингу (цит. за: [14]).

Більш чіткими, конкретними у визначенні цієї проблеми були знані ідеологи й адепти коучингу $[1 ; 4 ; 5$; та ін.], які пов'язади формування його теорії і методики, техніки $з$ певними вченнями, ідейними концептами і практиками минулого.

Аналіз згаданих та інших студій дає змогу стверджувати, що найбільш виразний, фундаментальний вплив на розвиток філософії коучингу справиди чотири ідейних учення та системні практики минулого й сучасного. Це: Сократівські методи діалогу; гуманістичний напрям психотерапії; роботи Денієла Гоулмена у сфері емоційного інтелекту; методики знаних спортивних тренерів [11]. 3'ясуємо їх предметно в контексті досліджуваної проблеми.

Незаперечний потужний вплив на формування теоретичних засад і технології коучингу (приміром, базова техніка постановки «сильних запитань» та ін.) справило вчення давньогрецького філософа Сократа (469-399 до н. е.). Ідеться про відомий метод Сократівських діалогів, якими він навчав співгромадян, як можна усвідомлено і власними силами поліпшити своє життя. На це вказували Дж. Уитмор, Г. Кимси-Хауз, Ф. Сандал у контексті аналізу творчості Т. Голві [8]. Інші автори поглибили розуміння цієї проблеми.

Відомий вислів давньогрецького мислителя «Я не можу нікого нічого навчити, я тільки можу змусити думати» можна вважати своєрідною квінтесенцією філософії коучингу. За допомогою запитань Сократ діагностував інтелектуальний потенціал своїх учнів і співгромадян та спонукав їх до роздумів про власне життя. Сутність цього методу подягає в тому, що, шукаючи відповіді на побудовані за певним алгоритмом запитання, людина могла б самостійно й усвідомлено дійти певних (правильних) висновків та зрозуміти, як сдід чинити, поводитися за тієї чи іншої ситуації. Не даючи готових рецептів і рішень, Сократ таким чином налаштовував співрозмовників на осмислений цілеспрямований пошук відповідей на нагальні життєві проблеми.

Вивчаючи цю проблему, В. Броск у нарисі «Вступ до історії коучингу» [9] відзначила ще одну парадоксальну й надваждиву схожість філософії Сократа та ідеології коучингу. Стверджуючи, що давньогрецький філософ ще у IV cт. до н. е. використовував «щось подібне на сучасний коучинг», авторка підкреслює, що мистецтво ставити запитання так, щоб допомогти слухачам міркувати й ухвалювати рішення зістин, які є в їхньому буденному житті, має глибші коріння. Воно було відоме як феномен «maieutike», що у перекладі $з$ грецької означає «мистецтво народжувати». Згідно з історичними даними, Сократ був сином акушерки, тож, за власним визнанням, він виконував подібну з матір'ю функцію, яка полягала в тому, щоб «щось дістати і доставити». «Пологи», які він приймав, - це «діставання» знань, які є всередині 
кожного. Сократ дише допомагав людині «вивести їх назовні» та передавав їх самій людині. У цьому полягає й одна з наріжних методологічних засад коучингу [9].

На ще одному значущому аспекті «коучингової філософії» Сократа акцентуе науковець А. Равієр. Утверджуючи тезу, згідно з якою «немає викладання, позаяк насправді існує лише учнівство», дослідник доводить, що істинні «знання є не в тренері, а в клієнтові / учневі». Отож, діалогічний метод Сократа ставить за мету набуття нових знань таким чином, щоб дюдина ставила під сумнів уже сформовані й передані їй зовні та самостійно шукала нове розуміння світу [13].

3'ясовуючи в унісон з означеними рефлексіями генезу коучингу, дослідник Р. Крауш стверджує, що коучинг - це «щось старе, як дюдство». Тож Сократ дише підкреслив через свої діалоги з учнями метод, заснований на істині, який виявляе заховане всередині особистості справжне знання. 3 цього випливає і сутність філософії коучингу та його головна мета - допомогти дюдині знайти себе [12].

У філософії і технології коучингу виразно відстежуємо постулати трьох основних взамопов'язаних напрямів гуманістичної психотерапії: екзистенційний («чутливий»); центрований («роджерський» - зосередженість на особистості); гештальт-психотерапія.

Головною метою екзистенційної психотерапії є допомога дюдині в пошуку сенсу життя, усвідомленні особистісної свободи та відповідадьності, розкритті власного потенціалу як особистості в спілкуванні і соціальному середовищі. Вона утверджуе постулат визнання дюдини як унікальної і самоцінної особистості. Один із засновників гуманістичної психології, американський психолог Карл Роджерс у центр своєї психотерапевтичної практики поставив особистість кдієнта, що «переживає безпорадність, закритість для істинного спілкування». На цій основі він обгрунтував знамениту гіпотезу, згідно з якою стосунки між клієнтом та психотерапевтом мають стати дієвою умовою, каталізатором позитивних особистісних змін. 3 огдяду на це, К. Роджерс визначив дві основні цілі психодогічної допомоги: 1) «допомогти особистісному самозростанню», завдяки чому дюдина має самостійно розв'язувати власні проблеми та стати «цілковито дієвою особистістю»; 2) створити для цього відповідний «психодогічний кдімат» (терапевтичні стосунки) [6].

Впадає в око схожість розробленої К. Роджерсом структури психотерапевтичного процесу і напрацьованої ідеологами коучингу схеми послідовної співпраці і впливу коуча на клієнта. Роджерська модель складається 3 шести етапів: 1) заблокованість клієнтом внутрішньої комунікації, його безсилдя перед чинними проблемам, відсутність бажання до змін; 2) самовираження, коди клієнт в атмосфері ухвалення рішення починає поступово відкривати власні переживання, усвідомлювати свої проблеми; 3) стимулювання саморозкриття і самосприйняття клієнта в усій складності, незавершеності, обмеженості власної особистості; 4) формування в клієнта готовності і здатності змінити ставлення до своєї феноменології: подолання самовідчуження, усвідомлення власного «Я», зростання потреби «бути самим собою»; 5) розвиток і інтегрування самоприйняття, відповідальності, особистісного досвіду (комунікація, поведінка, самовідчуття) в єдине ціле; 6) особистісні зміни: відкритість світові, собі, власному досвіду [6].

У теорії і практиці коучингу роджерівський підхід органічно поєднується із гештальт-психотерапією (нім. Gestalt - форма, кшталт, філософське поняття, що позначає об'єкт у його структурній цілісності, без розчленування на складники). Вона має виражену функційну спрямованість на посилення психологічних позицій особистості, розширення іï самосвідомості. Годовну мету щодо допомоги дюдині в реалізації свого потенціалу гештальт-психотерапія реалізуе на основі розв'язання таких завдань: 1) актуадізація самосвідомості дюдини; 2) стимулювання внутрішнього 
самоконтролю та особистої незалежності, самодостатності; 3) виявлення і подолання психодогічних бар'єрів, які гадьмують особистісне зростання. За такого підходу психотерапевт (як і в коучингу - коуч) розгдядаються як помічники і співтворці інтегрованої в «гештальт» (в єдине ціле) особистості. Психотерапевт уникає безпосереднього втручання у внутрішні інтимні почуття клієнта, але намагається полегшити їхнє самовияв лення [3; 7].

3 означеними психологічними феноменами коучингу гармонійно коредюють набутки теорії емоційного інтелекту, що була сформульована американським психодогом і письменником Д. Гоулманом. Учений виходив із постулату аксіоматичної взаємозалежності інтелекту і життевого успіху людини. При цьому не менший, а подекуди більш значущий вплив на їі життевий успіх справляе емоційний складник. На цій основі Д. Гоулман визначив і шукав відповіді на низку важдивих запитань: «Як емоційна сфера впливає на життєві здобутки людини?»; «Які емоційні складники формують долю?»; «Чи мождиво і як саме виправити емоційні моделі людини, що гадьмують іï поступ до кращого?». Ці та інші запити мади наблизити до з'ясування головного: «Якою є взаємозалежність емоційності та інтелекту?»; «Чи природна суперечність між емоційністю та інтелектом дюдини є нездоланою чи все-таки вони можуть доповнювати один одного?» [11].

Відповіді на ці й інші запитання Д. Гоулман виклав у книзі «Емоційний інтелект» [11], що стала бестселером та, як і його інші праці, набули популярності в західних інтелектуальних колах 90-х рр. XX ст. У філософії і технологіях коучингу виразно відстежуються гоулманські ідеї і результати психологічних експериментів, які 3 позицій нейрофізіології розкривають механізми активації психоемоційних станів.

Цілком природно, що коучинг продуктивно використовуе досвід спортивних тренерів. Цікавий і оригінальний погляд на це питання виклала згадувана науковиця В.Броск у фундаментальній праці «Джерельна книга 3 історії коучингу» [10]. Знана американська дослідниця і кваліфікована практикуюча тренерка стверджує, що сучасні коучі здебільшого неправильно розуміють багату й еклектичну історію тренерства (це поняття вживається як синонімічне коучингу), вважаючи, що вона бере початки з 80-х або 90-х рр. XX ст. Насправді їі коріння значно гдибші. Перші практики коучингу сягають гдибокої давнини. Його піонерами буди східні фідософи та стародавні спортивні тренери-практики. На Сході головне місце у фізичній підготовці посідади бойові мистецтва, на Заході - легка атлетика, про що свідчать зображення, зафіксовані на амфорах Стародавньої Греції [9; 10].

Спортивні тренери відіграли вагому роль у розвитку західної та східної культур, адже допомагали спортсменам досягати не лише фізичної, а й духовної досконалості. У XX ст. їхній досвід знайшов широке застосування: у 30-х рр. - у розвитку гуманістичної і трансперсональної психології; у 60-х рр. - у теоріях та ініціативах із розвитку людського потенціалу; у 70-х рр. - у сфері бізнесу; у 80-х рр. - у різних суспільних сферах. А 90-ті pp. XX - перше десятиліття XXI ст., зокрема у США, становлять «вибухову історію тренерства». Свідченням цього стало зростання чисельності програм спеціальної підготовки для тренерів (до 164 у 2004 році, асоціації професійних тренерів (до 12), щорічних тренерських конференцій (до 16), а також видання спеціалізованих фахових журналів та навчально-методичної дітератури різного гатунку. Розвиток коучингу в період постмодерну кінця XX ст. зумовив його проникнення зі сфери спорту в царину соціально-економічного життя, а також психологіі, бізнесу, освіти дорослих тощо [10].

Висновки. Проаналізовані теорії відомих зарубіжних учених у широкій історичній ретроспективі показують, як спортивне тренерство, акумулювавши 
тисячорічний досвід східної і західної культур із фізичного і духовного вдосконалення людини, трансформувалося в сучасний феномен коучингу, який проникнув у різні сфери завдяки своєму потужному потенціалу трансформувати й змінювати їхню якість. На такому тлі активно розвивалися тренерські практики, що стали важливим джерелом формування і розвитку теорії і технології коучингу. Зрозуміло, що чотири визначені ідейних вчення та практики минулого i сучасного не вичерпують розмаїття фундаментальних загальновідомих і тим паче індивідуальних (приватних), але не менш цікавих і продуктивних ідей, технік. Акумулюючи і творчо апробуючи їх у своїй діяльності, теоретики і практики коучингу випрацювали свої унікальні, продуктивні підходи та інструменти позитивного впливу на людину задля поліпшення ефективності різних сфер ії життєдіяльності та розв'язання професійних і особистих проблем. Бездіч промовистих фактів засвідчують мозаїчність і суб'єктну оригінальність такого досвіду. До прикладу, багато дослідників звертали увагу на потенційну або доведену доцільність використання в практиці коучингу ефекту плацебо. Чимало з них покдикалися при цьому на опубліковану 1922 р. книгу французького фармацевта Е. Куе, який, зважаючи на власний професійний досвід, висунув гіпотезу, згідно 3 якою несвідоме грає надзвичайно важливу роль у діяльності дюдини, так що нею можна цілеспрямовано маніпулювати та змінювати дюдське життя. Проаналізовані теорії відомих зарубіжних учених у широкій історичній ретроспективі показують, як спортивне тренерство, акумулювавши тисячорічний досвід східної і західної культур із фізичного і духовного вдосконалення людини, трансформувалося в сучасний феномен коучингу.

У подальших наукових дослідженнях плануємо проаналізувати підходи й засоби використання коучингу в закладах вищої освіти.

\section{Список використаних джерел:}

1. Аткинсон М., Чоис Т. Рае. Наука и искусство коучинга: Внутренняя динамика / пер. с ангд. Киев: Companion Group, 2009. 208 с.

2. Гэлиуэй Т.У. Теннис. Психология успешной игры. Олимп-Бизнес, 2010.208 c. URL: https://kniga.biz.ua >

3. Каліна Н. Ф. Психотерапія. Київ: Альма-матер. 2010. 288 с.

4. Дауни М. Эффективный коучинг: Уроки коуча для коучей / пер. с англ. Москва: Изд-во «Добрая книга», 2008. 288 с.

5. Парслоу Е., Рей М. Коучинг в обучении. Практические методы и техники. Санкт-Петербург: Питер, 2003. 204 с.

6. Роджерс К. Р. Взгляд на психотерапию. Становление человека. Москва: «Прогресс»; «Универс», 1994. 480 с.

7. Трач Р. Гуманістична психологія: у 3 т. Київ, 2005. Т. 2. 280 с.

8. Уитворд Д., Кимси-Хауз Г., Сандал Ф. Коактивный коучинг / пер. с ангд. Москва: Центр поддержки корпоративного управдения и бизнеса, 2004. 360 с.

9. Brock V. Introduction to coaching history. URL: http://www.vikkibrock.com/wpcontent/uploads/2012/06/UTD-Coaching-News-Introduction-to-Coaching-History.pdf

10. Brock G. V. Sourcebook of Coaching History. North Charleston SC: Createspace Independent Publishing Platform. 520 p.URL: https://essentialinstitute.org

11. Goleman D. Working with emotional intelligence. New York: Bantam Books, 1998. 464 p.URL: https://www.goodreads.com

12. Krausz R. R. Coaching executivo: A conquista da liderança. São Paulo: Nobel, 2007. URL: http://www.editoranobel.com.br > arquivos.

13. Ravier L. Coaching en Colombia: magazine coaching international. Madrid. 2016. Vol. 15, 41-43. URL: https://issuu.com/leoravier/docs/15 
Us ПЕДАГОГИНИЙ АЛЬМАНАХ. - 2021. - ВИПУСК 50

U3

14. Santos M. R. Coaching: A Brief Historical, Conceptual and Practical Analysis of the Method. Revista Científica Multidisciplinar Núcleodo Conhecimento,2020. № 4. P. 171-195. URL: https://www.nucleodoconhecimento.com.br/

\section{References:}

1. Atkynson, M., \& Choys, T. Rae. (2008). Nauka i iskusstvo kouchynha: vnutrenniaia dynamyka [The science and art of coaching: internal dynamics]. Kyiv: Companion Group [in Russian].

2. Galloway, T. W. (2010). Tennis. Psykholohyia uspeshnoi ihry [Tennis. Psychology of successful play]. Olymp-Byznes. Retrieved from https://kniga.biz.ua [in Russian].

3. Kalina, N. F. (2010). Psykhoterapiia [Psychotherapy]. Kyiv: Alma-mater [in Ukrainian].

4. Daun, M. (2008). Effektyvnyi kouchynh: Uroky koucha dlia kouchei [Effective coaching: Coach Lessons for coaches]. Moskva: Yzd-vo «Dobraiaknyha» [in Russian].

5. Parslou, E., \& Rei, M. (2003). Kouchynh $v$ obuchenyy. Praktycheskiemetody y tekhniky [Coaching in teaching. Practical methods and techniques]. Sankt-Peterburg: Piter [in Russian].

6. Rodzhers, K. R. (1994). Vzgliad na psikhoterapiiu. Stanovlenie cheloveka [A look at Psychotherapy. Becoming human]. Moskva: «Progress», «Univers» [in Russian].

7. Trach, R. (2005). Humanistychna psykholohiia [Humanistic Psychology]. Kyiv [in Ukrainian].

8. Uitvord, L., Kimsi-Khauz, G., \& Sandal, F. (2004). Koaktionyi kouching [Coactive Coaching]. Moskva: Tcentr podderzhki korporativnogo upravleniia i biznesa [in Russian].

9. Brock, V. (2012a). Introduction to coaching History. Retrieved from http://www.vikkibrock.com/wpcontent/uploads/2012/06/UTD-Coaching-News-Introduction-to-Coaching-History.pdf [in English].

10. Brock, G. V. (2012b). Source book of Coaching History. North Charleston SC: Create space Independent Publishing Platform. Retrieved from https://essentialinstitute.org [in English].

11. Goleman, D. (1998). Working with emotional intelligence. New York: Bantam Books. Retrieved from https://www.goodreads.com [in English].

12. Krausz, R. R. (2007). Coaching executivo: A conquista da liderança. São Paulo: Nobel. Retrieved from http://www.editoranobel.com.br $>$ arquivos [in English].

13. Ravier, L. (2016). Coaching en Colombia: magazine coaching international. Madrid, 15, 41-43. Retrieved from https://issuu.com/leoravier/docs/15> [in English].

14. Santos, M. R. (2020). Coaching: A Brief Historical, Conceptual and Practical Analysis of the Method. Revista Científica Multidisciplinar Núcleo do Conhecimento, 4, 171-195. Retrieved from https://www.nucleodoconhecimento.com.br/ [in English].

Savchuk B. P., orcid.org/0000-0003-2256-0845

Slyusarenko N. V., orcid.org/0000-0002-9215-5936

Bilavych H. $V$., orcid.org/0000-0002-1555-0932

\section{COACHING: IDEOLOGICAL ORIGINS IN THE PROJECTION OF PERSONALITY FORMATION}

The article is devoted to the problem of coaching, which at the beginning of the XXI century was widely recognized in Ukraine, in particular in the field of education. The purpose of the article is to determine ideological origins of coaching in order to better understand its philosophy and use it as an effective tool for personality formation.

It is stated that in the Ukrainian scientific and social discourse this problem is presented in a rather fragmentary way. In foreign science, many special studies are devoted to it, which are interdisciplinary (in the fields of sports, business, management, education, etc.) and mostly popular science. The authors emphasize that there is still no thorough comprehensive study of the problem of origin and history of the formation and development of coaching, as this problem is mainly covered by experts in various fields of knowledge from their narrow positions. In the Ukrainian scientific

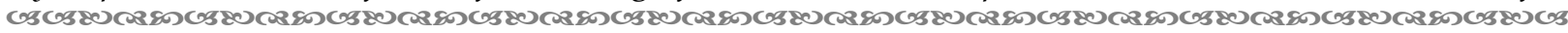
216 
and pedagogical discourse of coaching, a rather simplified model and a "narrowed" scheme of understanding the problem of the origin and formation of coaching has been established. Researchers emphasize the figure of the "founder" of modern coaching - California tennis coach, Harvard University professor W. Timothy Gallwey, who set out his cornerstone ideas in the book "The Inner Game of Tennis" and his several other bestsellers.

Based on the analysis of updated sources on this issue, it was concluded that the clearest and most fundamental influence on the development of the philosophy of coaching was made by four ideological teachings and systematic practices of the past and present. These are: Socratic methods of dialogue; humanistic direction of psychotherapy; D. Goleman's works in the field of emotional intelligence; methods of well-known sports coaches. Analyzed theories of well-known foreign scientists in a broad historical retrospective show how sports coaching, having accumulated millennial experience of Eastern and Western cultures in physical and spiritual improvement, has transformed itself into a modern phenomenon of coaching.

Key words: coaching, personality development, theories of origin, coaching, Socratic methods of dialogue, coach.

Дата надходженнястатті: 19.102021 p.

Рецензент: доктор педагогічних наук, доц̧ент Примакова В.В.

У, ДК 372.3.007

DOI https://doi.org/10.37915/pa.vi50.326

Султанова Н. В., orcid.org/0000-0003-3510-4662

\section{ФОРМУВАННЯ ПРОФЕСІЙНОЇ КОМПЕТЕНТНОСТІ КЕРІВНИКА ЗАКЛАДУ ДОШКІЛЬНОЇ ОСВІТИ У СИСТЕМІ ПІСЯЯДИПЛОМНОЇ ОСВІТИ: IСТОРІЯ ТА СУЧАСНІСТЬ}

У статті розкрито історико-педагогічні аспекти та сучасні організаційно-педагогічні засади процесу формування професійної компетентності керівників ЗДО в умовах установ післядипломної освіти, обьрунтовано можливості наступності дієвих механізмів та умов. Показано фактори впливу на підготовку та функційні обов'язки керівних кадрів у системі дошкільної освіти. Виявлено та представлено передумови розвитку освітніх установ та курсів для професійної підготовки педагогічних та керівних кадрів в Украӥні, у тому числі у галузі доикільної освіти.

Визначено актуальність формування професійної компетентності керівників закладів дошкільної освіти, яку ми трактуємо як динамічну комбінацію знань, умінь, навичок та інших особистісних $і$ ділових якостей, що визначають їхню здатність та гарантують готовність до професійного виконання керівних задач.

Розкрито основи управлінської культури керівників та зліст управлінської компетентності директорів дитячих садків. Проаналізовано Професійний стандарт Керівника закладу дошкільної освіти та виокремлено вимоги до його професійної діяльності у розрізі управлінських обов'язків та функцій. Наголошено, щзо формуванню професійної компетентності керівників закладів дошкільної освіти сприяе розвиток їхньої організаційної культури, у тому числі, у системі післядипломної освіти. Окреслено методологічне підррунтя професійного розвитку керівників ЗДО з позицій професійно-особистісного,

*(С) Султанова Н. В.

us 